\title{
Fracaso de la osteosintesis mandibular. Consideraciones biomecánicas y tratamiento. A propósito de dos casos clínicos
}

\author{
Mandibular osteosynthesis failure. Biomechanical and therapeutic considerations. Two clinical cases
}

La rancia controversia vivida en las dos últimas décadas del siglo $X X$ respecto a la osteosíntesis mandibular entre las escuelas franco-belga, seguidora de los planteamientos biomecánicos de Champy y los postulados de la AO-ASIF, ha quedado completamente desfasada. Los principios de las denominadas respectivamente "Fijación Semirrígida" y "Fijación Rígida Interna" se han establecido como simples técnicas quirúrgicas más que como filosofías enfrentadas y excluyentes entre sí, aceptándose universalmente hoy en día el concepto de "Fijación Adecuada" como el punto de encuentro entre ambas, eje central de lo que debe ser una correcta planificación terapéutica en cada caso concreto adaptada a las necesidades biomecánicas de cada individuo y su peculiar fractura u osteotomía.

El punto de partida es pues el identificar la realidad biológica del paciente y las características intrínsecas de su fractura para decidir con criterio, si es que el paciente precisa de osteosintesis, la técnica de fijación a emplear que proporcione una "Estabilidad Suficiente", una solución "Funcionalmente Estable" para el binomio hueso-placa, teniendo en cuenta que minimizar al máximo el periodo de fijación intermaxilar (FIM) debe de ser un objetivo prioritario a considerar, no solo para proporcionar al paciente un postoperatorio más confortable acortando en lo posible su periodo de "invalidez estomatognática", sino sobre todo para salir al paso de los efectos deletéreos bien conocidos del la FIM prolongada (enfermedad de la fractura, Robert Danis, 1949).

El diagnóstico se basa pues en un análisis global de la situación biológica del paciente, situación que puede por sí misma determinar el tipo de fijación necesaria para "garantizar" la curación de su fractura, saliendo al paso de potenciales complicaciones no solo locales, sino sistémicas en los casos en los que nos vemos obligados a reforzar una fijación insuficiente con un periodo de FIM prolongado en determinados pacientes pluripatológicos. De forma paralela, el análisis minucioso de las características mecánicas de su fractura resulta imprescindible para decidir con criterio. Se trata pues de entender algo tan sumamente simple, pero a menudo soslayado por la rutina y la vorágine asistencial, como que "no operamos radiografías sino pacientes".

Resulta, por lo tanto, y en mi opinión de capital importancia un proceso diagnóstico minucioso que contemple sistemáticamente todos estos parámetros para tomar nuestra decisión con criterio, con independencia de cual sea ésta, pero nunca sobre la simple acción de "echarnos una radiografía a la cara" para decidir. En este sentido, puede resultar muy útil un diagrama metodológico a aplicar en todos
The prolonged controversy regarding mandibular osteosynthesis that faced off the French and Belgian schools, followers of the biomechanical principles of Champy, against AO-ASIF postulates in the two last decades of the 20th century is now completely outdated. The principles of the techniques known, respectively, as "Semi-rigid Fixation" and "Internal Rigid Fixation", are now established as simple surgical techniques rather than competing, mutually exclusive, philosophies. The concept of "Adapted Fixation" currently is accepted universally as the point of encounter between the two positions, forming the central axis of proper therapeutic planning adapted to the biomechanical needs and the particular fracture or osteotomy of each individual patient.

The starting point is to identify the patient's biological reality and the intrinsic characteristics of the fracture in order to decide whether the patient in question requires osteosynthesis. A fixation technique must be chosen that provides "Sufficient Stability" and a "Functionally Stable" solution for the bone-plate binomial. Minimizing the maxillomandibular fixation period (MMF) must be a priority, not only to ensure the patient's postoperative comfort by shortening as much as possible the period of "stomatognathic disability" but, above all, to prevent the deleterious effects of prolonged MMF (fracture disease, Robert Danis 1949).

The diagnosis is based on a global analysis of the patient's biological situation, which can determine per se the type of fixation necessary to ensure fracture healing, forestalling potential local and systemic complications in cases in which an insufficient fixation must be reinforced with a period of prolonged MMF in certain patients with multiple pathologies. At the same time, meticulous analysis of the mechanical characteristics of the fracture is essential for rational decision-making. The aim is to understand the simple concept, often overlooked in the course of routine practice under the whirlwind pressures of care, that "we don't operate on radiographs, we operate on patients".

In my opinion a meticulous diagnosis that systematically takes weighs all these parameters is of capital importance in making well-informed decisions. It doesn't matter what the decision is, but it should never be based solely on the simple action of "making a radiograph of the face". An algorithm can be very useful for applying to all cases of mandibular fracture as a reasoned exercise for planning treatment, 
los casos de fractura mandibular como ejercicio razonado a la hora de planificar el tratamiento, es decir, tipo de abordaje a realizar, tipo de fijación que debemos emplear y necesidad de FIM. Un ejercicio que deberíamos exigirnos para con nuestros Residentes, insisto, en todos los casos (Tabla 1).

Consecuentemente a este pormenorizado análisis Médico-Quirúrgico estaremos en condiciones de etiquetar la situación Bio / Mecánica de cada fractura como de "Carga Compartida" o de "Carga Soportada" (Load Sharing vs Load Bearing en terminología anglosajona) para realizar una "Fijación Adecuada".

Conceptualmente, una situación de "Carga Compartida" es aquella en la que el paciente y su status biológico global se muestran capaces por sí mismos de "garantizar" la curación de su peculiar fractura; en estos casos, el papel de la osteosíntesis es secundario o coadyuvante, compartiendo la responsabilidad de la curación con el paciente y su hueso. En las situaciones de "Carga Soportada" por el contrario, bien la realidad biológica del paciente, bien las características de su fractura, bien ambas cosas en su conjunto, otorgan un protagonismo y una responsabilidad máxima al sistema de fijación en el proceso reparador y de consolidación ósea.

El "Fracaso de la Osteosíntesis" resulta pues habitualmente secundario a un desafortunado planteamiento terapéutico que no ha tenido en cuenta los principios mencionados, más que a errores en la técnica quirúrgica en sí misma, aunque resulta evidente que es necesario un adecuado entrenamiento puramente técnico y un mínimo de experiencia quirúrgica en el manejo de los implantes, sobre todo en aquellos más potentes de fijación bicortical.

Aciertan los autores en su idea de presentarnos dos fracasos estrepitosos (incluso reincidente en el primer caso) derivados de un incorrecto planteamiento biomecánico, aunque discrepo de su afirmación de que estas situaciones son infrecuentes. Muchos de nuestros pacientes son sometidos a periodos de FIM más o menos prolongados que podrían haberse evitado de haber empleado una fijación adecuada, aunque ciertamente la inmensa mayoría no necesitan volver a pasar por quirófano. Sospecho además que existen otros muchos fracasos de osteosíntesis que por su discreta trascendencia clínica no reingresan en nuestros hospitales y que por un motivo $u$ otro acaban conviviendo con un mal resultado funcional que quizás podría haberse evitado. which includes the type of approach and fixation to be used and the need for MMF. This is an exercise that we should demand from our interns in every case (Table 1).

After this detailed medical and surgical analysis we will be better prepared to assess the biomechanical situation of each fracture as "Load Sharing" or "Load Bearing" in order to design the appropriate "Adapted Fixation".

Conceptually, a load-sharing situation is one in which the patient and the patient's overall biological status are capable of ensuring the healing of a particular fracture. In these cases, osteosynthesis has a secondary or coadjuvant role and the task of healing is shared between the patient and the bone. In load-bearing situations, in contrast, either the patient's biological circumstances or the fracture characteristics, or both, are such that the fixation system plays a prominent role in the repair process and bone consolidation.

Osteosynthesis failure usually is secondary to an unfortunate therapeutic approach in which the principles cited above have not been properly assessed, rather than to errors in the surgical technique. Nonetheless, it is evident that technical skill and a minimum surgical experience in the management of implants are necessary, particularly with the stronger bicortical fixation implants.

The authors are right in their idea of presenting two resounding failures (a double failure in the first case) as the result of an incorrect biomechanical assessment, although I do not agree with their claim that these situations are uncommon. Many of our patients undergo more or less prolonged periods of MMF that could have been avoided if suitable fixation had been used, although most of them do not have to return to the operating room. I also suspect that 
De ambos casos presentados por los Autores podríamos sacar muchas enseñanzas, que me permito detallar:

En el primer caso, nos encontramos con una paciente afecta de síndrome de Down que presenta una fractura doble, de cuerpo izquierdo y ángulo derecho. Tan solo estos dos datos son suficientes para etiquetar la situación inequívocamente como de "Carga Soportada". Debo de discrepar con los autores cuando afirman que un paciente poco colaborador precisa de FIM: en mi opinión es precisamente todo lo contrario. Un paciente con Sd. de Down no debe de ser candidato a un bloqueo intermaxilar aunque solo sea por su falta de colaboración más o menos profunda. Pero además en este caso, su doble fractura es en si misma "compleja" o no simple. Se le realiza una osteosíntesis "remix" con miniplacas, abordaje extraoral incluido en el lado derecho (creo que inaceptable) que se muestra insuficiente para proporcionar la estabilidad necesaria en este caso. Cabe interpretar por la radiografía panorámica que esta criatura tuvo un proceso de osteomielitis focal en el ángulo derecho que la llevó a perder su segundo molar y a verse sometida a un prolongado periodo de FIM con tornillos máxilo-mandibulares en un intento de solucionar el problema. Nuevo error, que no hace sino retrasar lo inevitable, es decir la reintervención y nueva fijación. Desafortunadamente, esta segunda intervención fracasa, siendo altamente probable pensar que ello no fue debido a la presencia de gérmenes especialmente patógenos ni a la falta de higiene de la paciente. La placa de reconstrucción 2.5 está colocada en mitad de ningún sitio, en la zona neutra del ángulo-cuerpo mandibular, con al menos tres tornillos haciendo certera diana en el trayecto del nervio dentario inferior y, lo que es más trascendente, con uno de ellos insertado en el foco de fractura. La técnica de osteosíntesis puente ha sido errónea, puesto que está sólidamente establecido que la placa de reconstrucción debe de ser colocada en la basal, puenteando la zona problema generosamente e insertando al menos tres tornillos a ambos lados de ésta (mejor cuatro) sobre hueso sano. En esta ocasión, el error es más técnico que conceptual (que también lo es) pero resulta nuevamente fatal. La presencia de una miniplaca tipo "lock" en la basal es puramente anecdótica por inútil desde there are many other patients with osteosynthesis failures of discrete clinical importance that are not readmitted to hospitals and, for one reason or another, end up coexisting with a poor functional result that might have been avoided.

We can learn much from the two cases presented by the authors, which I will discuss in detail:

The first case was a patient with Down's syndrome who had a double fracture of the left mandibular body and right angle. These two elements of information suffice to label the situation unequivocally as load-bearing. I have to disagree with the authors' claim that uncooperative patients may require MMF: in my opinion, the opposite is true. A patient with Down's syndrome should not be a candidate for maxillomandibular fixation, even if only because of their lack of cooperation. However, this patient had the additional problem of a "complex," or not simple, double fracture. Mixed osteosynthesis was performed using with small plates with an extraoral approach on the right side (which I believe is unacceptable) that failed to provide the necessary stability in this case. The evidence of the panoramic radiograph can be interpreted as indicating that this woman had focal osteomyelitis of the right angle that caused her to lose her second molar. She had to undergo prolonged MMF with maxillo-mandibular screws in an attempt to solve the problem. This was another error, doing no more than delay the inevitable reintervention and new fixation. Unfortunately, the second intervention failed, probably not due to the presence of especially pathogenic germs or the patient's lack of hygiene. The 2.5 reconstruction plate was not placed in the middle of any locus, it was placed in the neutral zone of the mandibular angle-body. At least three screws were placed accurately in the trajectory of the inferior dental nerve and, more importantly, one of them was inserted in the fracture 
el punto de vista biomecánico. Cabe pensar que tras cinco meses de osteomielitis focal con sus típicas reagudizaciones y estériles períodos de FIM asociados a kilogramos de antibióticos por distintas vías la paciente terminó por recibir la tercera y definitiva Cirugía Reconstructiva con empleo de injerto óseo inmediato y una osteosíntesis puente "ad hoc". Es de destacar que la presencia de un fracaso de la consolidación sobreinfectado (osteomielitis focal) no es contraindicación para la realización de un injerto óseo no vascularizado, siempre que la osteosíntesis sea la adecuada y proporcione por sí misma la estabilidad suficiente para una curación ósea sin perturbaciones mecánicas que la aborten. Finalmente, debemos de suponer que la panorámica de control no es la correspondiente a un año del postoperatorio sino al postoperatorio inmediato, sopena que los tornillos FIM hayan quedado olvidados bajo la mucosa. Sea como sea, destacar que aún con el injerto, la FIM no es necesaria, no aporta absolutamente nada a la revascularización y viabilidad del injerto cuando la fijación es la adecuada y la cobertura de partes blandas suficiente.

En el segundo caso presentado, nos encontramos ante el típico fracaso de una fijación con miniplacas para una mandíbula con atrofia moderada, con una fractura en "slide" desfavorable y con fracturas bicondíleas bilaterales que deberían exigirnos a priori una movilización activa precoz: inequívocamente, situación de Carga Soportada. La ortopantomografía postoperatoria habla por sí misma, evidenciándose una reducción inadecuada (es de suponer que por un abordaje intraoral) y una osteosíntesis a todas luces insuficiente. Meses después vemos la típica pseudoartrosis avascular con fracaso de la consolidación y colapso del fragmento proximal de la mandíbula. Aún en ausencia de sobreinfección, esta situación es funcionalmente inaceptable. La cirugía reparadora practicada nuevamente muestra que la realización de injertos óseos resulta electiva en estos casos cuando el defecto es mayor de $1 \mathrm{~cm}$. Nuevamente debo de suponer que la ortopantomografía corresponde al postoperatorio inmediato y no a los 6 meses, debido a la presencia de los tornillos FIM.

Finalmente $y$, aunque de forma somera, se describen los beneficios de las placas de bloqueo para la fijación de fracturas y defectos mandibulares. Es bien conocido que en las placas convencionales la estabilidad se obtiene como consecuencia de una perfecta adaptación de las mismas al perfil óseo y a la compresión perpendicular que ejercen los tornillos entra aquella y éste. Se ha demostrado que esta compresión compromete la vascularización de la cortical ósea, pudiendo comprometer la consolidación en casos desfavorables. En las placas de bloqueo, la estabilidad del sistema de osteosíntesis depende de la unidad mecánica que conforman la placa con los tornillos engarzados en sus agujeros (a modo de un fijador externo) minimizando así la compresión focal sobre la cortical, lo que favorece la revascularización del foco y la curación de la fractura. El empleo por tanto de los sistemas de bloqueo tipo Unilock, resulta electivo en estos casos comprometidos o complicados tanto de forma inicial como a consecuencia de un fracaso.

En conclusión y, partiendo de la base de que cualquier paciente puede complicarse en las mejores manos, debemos de realizar un ejercicio de autocrítica sobre nuestros errores y fracasos, echan- locus. The bridge osteosynthesis technique was erroneous because it is well established that the reconstruction plate must be placed in the basal area, generously bridging the fracture area. At least three screws (and better four) must be inserted on both sides of the plate in healthy bone. On this occasion, the error was more technical than conceptual (although it also was conceptual) and the outcome was failure. The presence of a small locking plate in the basal is anecdotic because it was biomechanically useless. It may be thought that after five months of focal osteomyelitis with its typical exacerbations and sterile periods of MMF associated with kilograms of antibiotics by different routes the patient only received the third and definitive reconstructive surgery with an immediate bone graft and bridge osteosynthesis by chance. It is noteworthy that the presence of an infected consolidation failure (focal osteomyelitis) is not a contraindication for performing nonvascularized bone graft, as long as the osteosynthesis is adequate and provides sufficient stability for bone healing without counterproductive mechanical disturbances. Finally, we must assume that the followup panoramic radiograph was not made at one year of the postoperative period, but in the immediate postoperative period, and that there is a risk that MMF screws may have been overlooked under the mucosa. Whatever the case, it should be emphasized that even with the graft, MMF was not necessary and does not contribute anything to graft revascularization and viability when fixation is adequate and soft tissue coverage is sufficient.

In the second case presented, we have a typical failure of fixation with small plates in a jaw with moderate atrophy, an unfavorable "slide" fracture, and bilateral condylar fractures that require early active mobilization: This is unequivocally a load-bearing situation. The postoperative orthopantomography speaks for itself, showing inadequate reduction (presumably by an intraoral approach) and an obviously insufficient osteosynthesis. Months later, the typical avascular pseudoarthrosis with consolidation failure and collapse of the proximal mandibular fragment was evident. Even in the absence of infection, this situation is functionally unviable. The repair surgery performed confirmed that bone grafts are of choice in cases in which the defect is more than $1 \mathrm{~cm}$ wide. Again, I have to assume that the orthopantomography shown is from the immediate postoperative period and not 6 months, due to the presence of MMF screws.

Finally, the authors briefly discuss the benefits of locking plates for the fixation of fractures and mandibular defects. It is known that stability is achieved with conventional plates by the perfect adaptation of the plate to the bone profile and perpendicular compression by the screws of the plate against the bone. It has been demonstrated that compression jeopardizes the vascularization of the cortical bone, which may unfavorably affect consolidation. In locking plates, the stability of the osteosynthesis system depends on the mechanical unit of the plate affixed by its screws (as a an external locking device), which diminishes the focal compression of 
do la vista atrás y planteándonos que podría haber sucedido o haberse evitado si nuestra elección-planificación hubiese sido otra. Muy probablemente, llegaremos a la conclusión que hace ya algún tiempo nos trasmitió un Maestro:

"Muy pocas veces, con una técnica quirúrgica depurada, nos arrepentiremos de utilizar un sistema de fijación más potente y, por el contrario, en muchas ocasiones nos arrepentiremos de no haberlo hecho" Prof. Brian Alpert

\section{Sergio Martínez-Villalobos Castillo}

Grupo AO España CMF

Member European AO-CMF Specialty Board Hospital Universitario "Virgen de las Nieves". Granada. España the cortical and favors locus revascularization and fracture healing. Therefore, the use of Unilock type locking systems is a technique of choice in cases that are compromised or complicated either initially or as a consequence of failure.

In conclusion, and parting from the idea that any patient may experience complications even in the best hands, we must critically examine our errors and failures, looking backward to consider what might have ensued or been avoided if our selection or planning had been different. More likely, we will reach the same conclusion that once was transmitted to us by a Master:

"We will rarely regret using a stronger fixation system when using a clean surgical technique but, in contrast, on many occasions we will regret not using one."

Prof. Brian Alpert 